\title{
SPARTINA ANGLICA COLONISATION AND PHYSICAL EFFECTS IN THE TAMAR ESTUARY, TASMANIA 1971-91
}

\author{
by Ada W. Pringle (née Phillips) \\ (with three tables and eight text-figures)
}

Pringr.f, A.W., 1993 (31:viii): Spartina anglica colonisation and physical effects in the Tamar estuary, Tasmania 1971-91. Pap. Proc. R. Soc. Tasm. 127: 1-10. https://doi.org/10.26749/rstpp.127.1 SSN 0080-4703. Depanment of Geography, Lancaster University, Lancaster LAl 4YB, UK.

The extent, form and condition of Spartina anglica in the Tamar Estuary changed between the summer of 1971/72 and 1991, probably due to differences in maturity and substrate. This exotic saltmarsh grass stabilised and raised the intertidal mudflats and constrained channel movements, but it has also reduced recreational facilities and its spread is largely uncontrollable.

Key Words: Spartina, saltmarsh, estuary, Tasmania.

\section{INTRODUCTION}

The main characteristics of the Tamar Estuary (fig. 1) were formed when a rise in sea level of approximately $60 \mathrm{~m}$, between about 13000 and 6500 yrs BP, drowned the preexisting river valley (Thom \& Roy 1985). The $61 \mathrm{~km}$ long estuary, extending between Launceston and Low Head on Tasmania's Bass Strait coast, follows a winding course of variable width, with wider basins separated by narrower reaches. A single major navigable channel is flanked by broad intertidal mudflats in the basins, although these become narrow or absent in the constricted reaches.

It was into these mudflats at Windermere that Spartina anglica was first introduced in 1947 (Ranwell 1967, Phillips 1975); Boston (1981) provided further details. Plants from Buckland Park, South Australia, were obtained for the Marine Board of Launceston by the Tasmanian Department of Agriculture. The original planting at Buckland, in the intertidal zone of the Gawler River, was in January 1931; the plants were sent from England (by E. V. Oliver of University College, London, and R. Cartridge of Poole Harbour, Dorset) to the Department of Agriculture, Adelaide. As recorded by Martin (1971), an agronomist with the Tasmanian Department of Agriculture, Launceston, Spartina was introduced to the Tamar in an attempt to

stabilise the mud flats so that they would eventually be above high water level and become relatively useful land and in the hope that this would

force the stream flow into the central part of the river, creating a scouring effect and keeping the main channel relatively free of mud.

Additional plantings, using local material, were carried out up to 1964. During the early 1960s, Spartina appeared rapidly and extensively on neighbouring intertidal mudflats (Phillips 1975). The spread was achieved partly by rooting of broken fragments distributed by tidal currents and also by seeding (a 15\% germination rate was proved by the Department of Agriculture). By the summer of 1971/72, Spartina covered over 500 ha (fig. 2) in a $29 \mathrm{~km}$ stretch of the central Tamar between Dilston-Dog Point upstream and East Arm-Ruffins Bay downstream (Pringle 1975).

\section{SPARTINA SURVEYS SINCE 1971/72 SUMMER}

Following the detailed field investigations of $1971 / 72$, more limited surveys have been undertaken during short return visits to Tasmania. Tidal relationships of the Spartina marsh were investigated in 1977 (Pringle 1982). The extent and form of Spartina colonisation in the Tamar Estuary were mapped in the field in August 1983, April-May 1988 and September-October 1991, and were plotted on 1:72000 base maps, as used also in the 1971/72 field survey. Areas on the intertidal mudflats with continuous Spartina sward were distinguished from those containing separate rounded clumps and isolated shoots, as in the earlier field survey. Mapping was carried out from the shore mainly, but the marsh was inspected also from the river, enabling more inaccessible shores to be mapped. When aerial surveys (table 1) had been carried out near to the dates of the field surveys, the photographs were used to cross-check with the field mapping. These were especially important for establishing the limits and form of the most extensive area of

TABLE 1

Aerial surveys used in this study

\begin{tabular}{lcl}
\hline Date/project & Scale & \multicolumn{1}{c}{ Remarks } \\
\hline $\begin{array}{l}\text { 22.12.74 } \\
1976 \text { census, Launceston }\end{array}$ & $1: 40000$ & $\begin{array}{l}\text { Mid-tide to HW, some } \\
\text { saltmarsh visible }\end{array}$ \\
$\begin{array}{l}\text { 19.1.83 \& 13.2.83 } \\
\text { M263 Tamar Valley }\end{array}$ & $1: 15000$ & $\begin{array}{l}\text { Mid-tide, much salt- } \\
\text { marsh visible }\end{array}$ \\
$\begin{array}{l}\text { 29.10.84 } \\
\text { M492 Tamar Valley }\end{array}$ & $1: 15000$ & $\begin{array}{l}\text { Timed across LW at } \\
\text { Rosevears, all saltmarsh } \\
\text { visible }\end{array}$ \\
$\begin{array}{l}\text { 17.12.87 } \\
\text { M169 Tamar Valley OPM }\end{array}$ & 128000 & $\begin{array}{l}\text { About LW at Rosevears, } \\
\text { all saltmarsh visible }\end{array}$ \\
2.2.91 & $1: 15000$ & $\begin{array}{l}\text { Abour LW, all saltmarsh } \\
\text { visible }\end{array}$ \\
\hline \begin{tabular}{l} 
M919 Upper Tamar \\
\hline
\end{tabular}
\end{tabular}




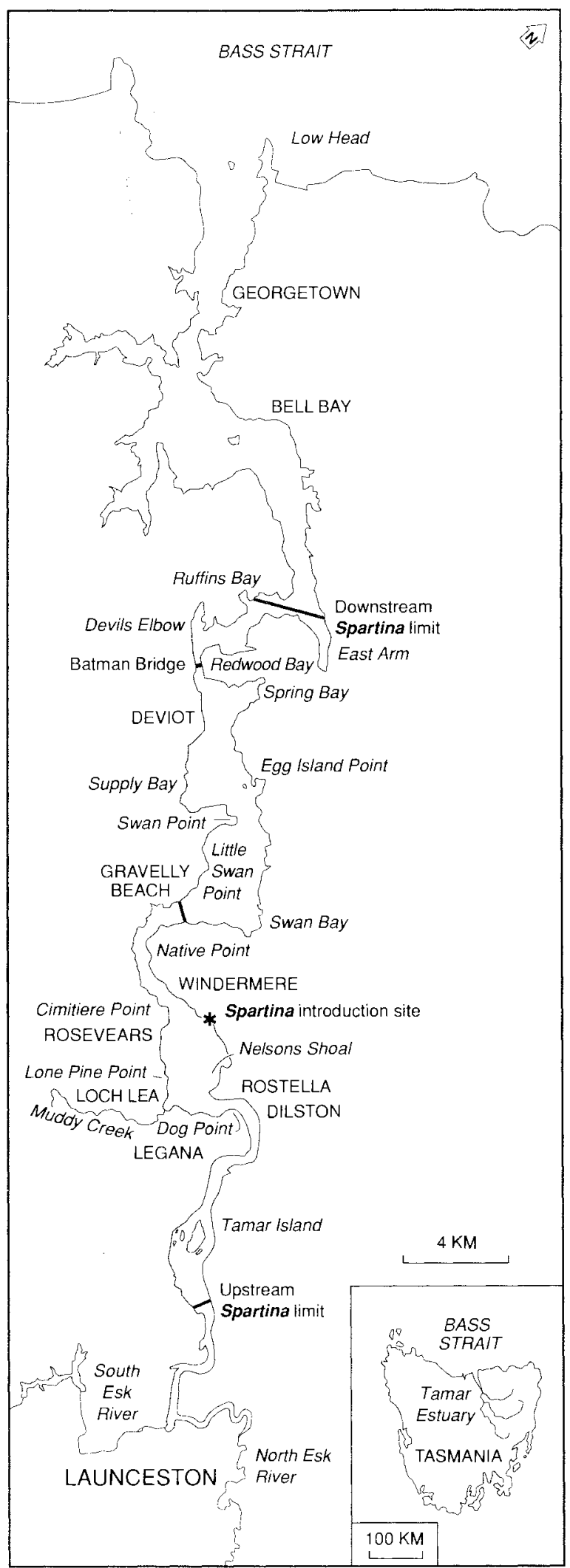

FIG. 1 - Location map of Tamar Estuary.

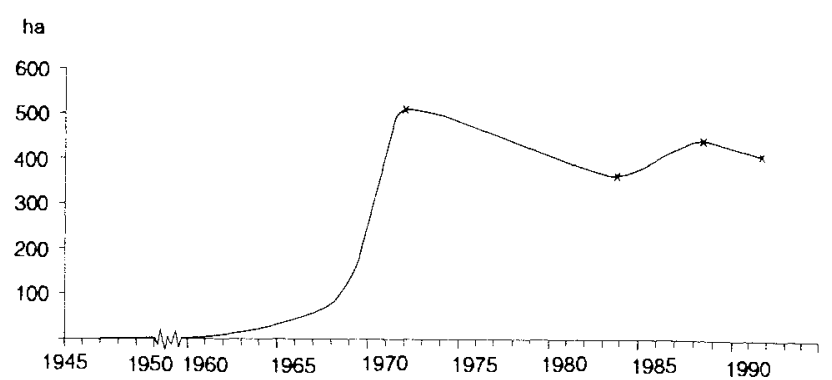

FIG. 2 - Area of Spartina anglica in Tamar Estuary 19471 91. Based on aerial surveys, except 1971/72, and field surveys (x) from 1971/72 onwards.

Spartina marsh on Nelsons Shoal. A colour aerial survey, at 1:15 000, flown about low water (LW) on 2 February 1991, covered the whole stretch of the Tamar Estuary where Spartina is colonising (except for East Arm and part of Ruffins Bay); this was particularly valuable for the 1991 field survey.

In addition to the general field mapping of the Spartina marsh, replicate cross-profile surveys have been carried out, using an automatic level. A transect line established between high and low water marks (HWM and LWM) at Rosevears (fig. 1) in January 1972 was resurveyed in August 1977 , August 1983, April 1988 and September 1991. New transect lines were established in collaboration with the Port of Launceston Authority (PLA) in August 1983 at Windermere and Swan Bay (fig. 1). In addition to surveys of them by the author in August 1983, April 1988 and October 1991, these cross-profiles and that at Rosevears were surveyed by the PLA in August each year between 1984 and 1989. (Full records are kept by the PLA.)

As well as the Tamar Estuary Spartina survey in 1988, a general inspection and survey was made of Spartina colonisation in other Tasmanian Bass Strait estuaries (Pringle 1988), into which plants from the Tamar had been introduced between 1949 and 1974 (Boston 1981).

\section{OVERALL EXTENT OF SPARTINA MARSH}

The area calculations for Spartina in the Tamar Estuary (fig. 2) were based on aerial surveys alone up to 1970 . As noted earlier (Phillips 1975), for Spartina to be recognised on these aerial photographs, which ranged in scale between 1:51 480 and 1:6336, it must be growing densely, in either a continuous sward or closely spaced clumps. The detailed field survey of 1971/72 enabled the distribution of isolated shoots also to be mapped; therefore the total areal extent (555 ha) of Spartina for that summer is not strictly comparable with the earlier calculations. In addition, it appears from later aerial surveys that there was an overestimation of the area of Spartina on the Nelsons Shoal mudflats in 1971/72. (Facilities had not been available then for a detailed instrumental ground survey of this treacherous intertidal area.) By making due allowance for both these factors, it appears that an area of 512 ha is more closely comparable with the calculations for earlier years.

The more general field surveys carried out in 1983, 1988 and 1991 enabled areas of sward, clumps and isolated shoots to be mapped, although the shoots were those growing in close proximity to the clumps rather than alone along a shoreline, as mapped in places in 1971/72. As indicated above, Spartina distribution was checked on aerial photo- 
graphs (table 1), where these were available for dates near those of the ground surveys. The area calculations are, therefore, comparable with those for earlier years.

The explosive nature of the Spartina colonisation in the Tamar Estuary between the summers of 1968/69 and 1970/ 1971, after slower initial establishment between 1947 and 1968 (fig. 2), was considered earlier (Phillips 1975). The intertidal mudflats provided a vacant niche, which previously had been colonised only by the algae Enteromorpha. Near HWM limited saltmarsh had developed, with Sarcocornia quinqueflora as the main primary coloniser and the rear of the marsh dominated by Phragmites, Juncus and Gabnia. The sudden rapid expansion of Spartina into this vacant niche was probably the result of an unusually good year(s) for seedling establishment, following an infrequent episode of considerable seed production. Similar rapid bursts of colonisation have been noted in several British estuaries; the Conway Estuary in North Wales (Gray et al. 1990), Morecambe Bay, northwestern England (Whiteside 1987) and Cromarty Firth, Scotland (Smith 1982). Marks \& Mullins (1990) investigated seed production in a range of English Spartina marshes, and concluded that tidal range, date of inflorescence emergence, soil temperature and salinity were all important influencing factors. Gray et al. (1990) note that is is not yet known what constitutes a good year for seedling establishment; temperature, tide-related phenomena such as mudflat elevation, and/or genetic reasons may provide an explanation.

Because of the 11-year gap between the 1971/72 and 1983 field surveys, only an overall downward trend in Spartina area to 367 ha can be deduced (fig. 2). This was followed by an increase in area to 447 ha in 1988 but subsequently a reduction to 412 ha in 1991 .

\section{VARIATIONS IN SPARTINA DISTRIBUTION}

Variations in the distribution pattern of Spartina colonisation were apparent during the field mapping and subsequent area calculations based on the 1:72000 maps. In table 2, separate data for sward and for clumps and shoots are listed for the western and eastern shores of the Tamar, and also for sections of the estuary upstream and downstream from a line through Gravelly Beach (GR 979291) to the eastern shore opposite (GR 986285) (fig. 1). The upstream section extends to the shores slightly upstream of Tamar Island, although Spartina covers relatively small areas above Dilston on the eastern shore and Dog Point on the western shore. The downstream section extends to East Arm and Ruffins Bay. The winding nature of the Tamar Estuary, with alternating basins and narrow reaches, has already been noted. The line through Gravelly Beach divides the area where Spartina is colonising into an upstream basin, with narrower stretches above and below, and a larger downstream basin, leading to a narrow stretch near the downstream limit of growth.

When the areal distribution of Spartina is examined separately on each shore of the Tamar, during the period $1971 / 72$ to 1991 (fig. 3, tables 2 \& 3), it is immediately apparent that the area occupied on the eastern shore is over twice that on the western shore. In 1971/72, on the eastern shore the area of sward was nearly twice that of clumps and shoots, whereas on the western shore the areas were similar. By 1983, the area of sward on both shores had increased slightly, and the overall reduction shown in Spartina area resulted from a pronounced fall in the area of clumps and shoots to about $9 \%$ of the total area on the eastern shore and $15 \%$ on the western shore. The overall increase in Spartina area between 1983 and 1988 was brought about by an increased in sward area on both shores whilst a slower reduction in area of clumps and shoots occurred. The slight reduction in total Spartina area between 1988 and 1991 reflects a similar reduction in area of sward on both shores, combined with a continued slow reduction in area of clumps and shoots on the eastern shore although there was a slight increase on the western shore.

When the areal distribution of Spartina is considered upstream of Gravelly Beach, it is clear that nearly twice the area is colonised, as compared with downstream, and other differences also emerge during the 20-year period (Fig. 4, tables $2 \& 3$ ). In $1971 / 72$, in the upstream section $86 \%$ of
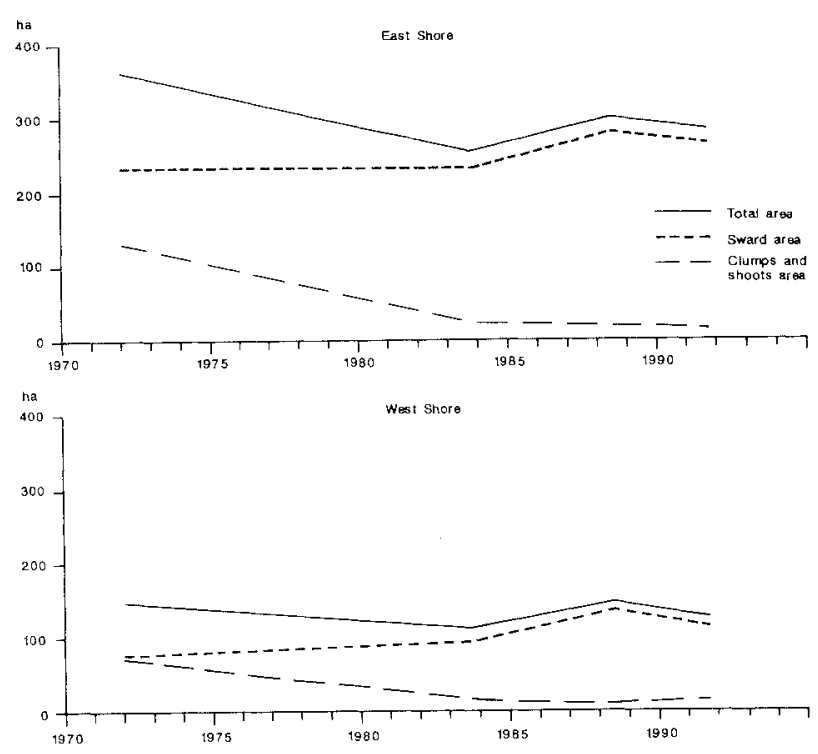

FIG. 3 - Area of Spartina anglica on eastern and western shores of Tamar Estuary, $1971 / 72$ to 1991.

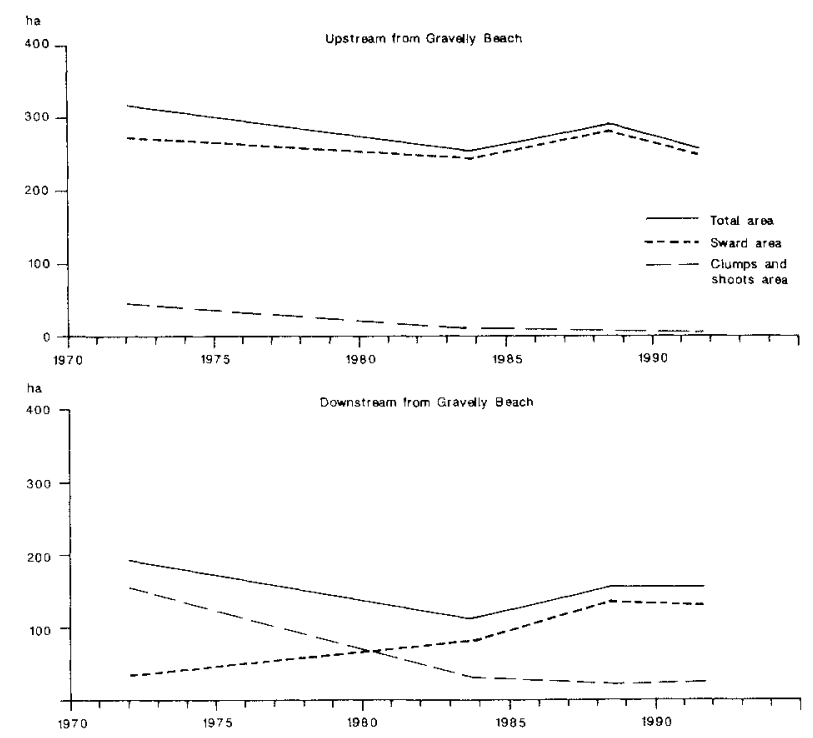

FIG. 4 - Area of Spartina anglica upstream and downstream from line through Gravelly Beach, Tamar Estuary $1971 / 72$ to 1991 (see fig. 1). 
TABLE 2

Area of Spartina anglica in the Tamar Estuary (ha)

\begin{tabular}{|c|c|c|c|c|c|c|c|c|c|}
\hline \multirow{2}{*}{$\begin{array}{l}\text { Estuary } \\
\text { section }\end{array}$} & \multicolumn{3}{|c|}{ Western shore } & \multicolumn{3}{|c|}{ Eastern shore } & \multicolumn{3}{|c|}{ Total } \\
\hline & Sward & $\begin{array}{l}\text { Clumps } \\
\text { \& shoots }\end{array}$ & Total & Sward & $\begin{array}{l}\text { Clumps } \\
\& \text { shoots }\end{array}$ & Total & Sward & $\begin{array}{l}\text { Clumps } \\
\text { \& shoots }\end{array}$ & Overall \\
\hline \multicolumn{10}{|c|}{ November 1971/January 1972} \\
\hline Upstream * & 63.38 & 16.50 & 79.88 & 210.38 & 28.63 & 239.01 & 273.76 & 45.13 & 318.89 \\
\hline Downstream $t$ & 13.25 & 55.63 & 68.88 & 22.25 & 101.88 & 124.13 & 35.50 & 157.51 & 193.01 \\
\hline Total & 76.63 & 72.13 & 148.76 & 232.63 & 130.51 & 363.14 & 309.26 & 202.64 & 511.90 \\
\hline \multicolumn{10}{|l|}{ August 1983} \\
\hline Upstream & 66.25 & 4.50 & 70.75 & 178.25 & 5.75 & 184.00 & 244.50 & 10.25 & 254.75 \\
\hline Downstream & 28.13 & 12.63 & 40.76 & 53.25 & 18.25 & 71.50 & 81.38 & 30.88 & 112.26 \\
\hline Total & 94.38 & 17.13 & 111.51 & 231.50 & 24.00 & 255.50 & 325.88 & 41.13 & 367.01 \\
\hline \multicolumn{10}{|c|}{ April-May 1988} \\
\hline Upstream & 89.38 & 2.00 & 91.38 & 192.38 & 6.75 & 199.13 & 281.76 & 8.75 & 290.51 \\
\hline Downstream & 48.13 & 8.00 & 56.13 & 87.38 & 13.38 & 100.76 & 135.51 & 21.38 & 156.89 \\
\hline Total & 137.51 & 10.00 & 147.51 & 279.76 & 20.13 & 299.89 & 417.27 & 30.13 & 447.40 \\
\hline \multicolumn{10}{|c|}{ September-October 1991} \\
\hline Upstream & 67.50 & 1.13 & 68.63 & 180.38 & 5.63 & 186.01 & 247.88 & 6.76 & 254.64 \\
\hline Downstream & 44.63 & 14.88 & 59.51 & 85.88 & 11.63 & 97.51 & 130.51 & 26.51 & 157.02 \\
\hline Total & 112.13 & 16.01 & 128.14 & 266.26 & 17.26 & 283.52 & 378.39 & 33.27 & 411.66 \\
\hline
\end{tabular}

* Upstream from Gravelly Beach to south of Tamar Island.

$\dagger$ Downstream from Gravelly Beach to Ruffins Bay/East Arm.

TABLE 3

Proportion of Spartina anglica in sectors of Tamar Estuary (\% of total Spartina area)

\begin{tabular}{llrrr}
\hline Survey & Estuary section* & $\begin{array}{c}\text { Western } \\
\text { shore }\end{array}$ & $\begin{array}{c}\text { Eastern } \\
\text { shore }\end{array}$ & Total \\
\hline \multirow{2}{*}{$1971 / 72$} & Upstream & 15.60 & 46.69 & 62.29 \\
& Downstream & 13.46 & 24.25 & 37.71 \\
& Total & 29.06 & 70.94 & 100.00 \\
\multirow{1}{*}{1983} & Upstream & 19.29 & 50.12 & 69.41 \\
& Downstream & 11.11 & 19.48 & 30.59 \\
& Total & 30.40 & 69.60 & 100.00 \\
& & & & \\
1988 & Upstream & 20.42 & 44.51 & 64.93 \\
& Downstream & 12.55 & 22.52 & 35.07 \\
& Total & 32.97 & 67.03 & 100.00 \\
& & & & \\
1991 & Upstream & 16.67 & 45.18 & 61.85 \\
& Downstream & 14.46 & 23.69 & 38.15 \\
& Total & 31.13 & 68.87 & 100.00 \\
\hline
\end{tabular}

* As for table 2 . 
the total Spartina area was sward, with only $14 \%$ clumps and shoots, and the proportion of sward subsequently increased to $96 \%$ in 1983 , and $97 \%$ in 1988 and 1991 . The variations in total Spartina area were reflected in similar trends in sward area, whilst there was a continuous reduction in area of clumps and shoots.

By contrast, in the section downstream of Gravelly Beach in $1971 / 72$ the proportions were almost reversed, with sward covering only $18 \%$ of the total Spartina area, whereas clumps and shoots covered $82 \%$. However, by 1983 the sward area had increased to $72 \%$ of the total, by 1988 to $86 \%$, followed by a small reduction to $83 \%$ in 1991 . The reduction in total Spartina area between 1971/72 and 1983 was mirrored in the reduction in area of clumps and shoots, whilst the sward area increased. Subsequently, changes in the total area were reflected in the increase in sward area to 1988 and its slight reduction in 1991, whilst the area of clumps and shoots decreased slightly to 1988 , before increasing slightly to 1991 .

When the sections of the Tamar Estuary upstream and downstream of the line through Gravelly Beach are subdivided into eastern and western shores, it can be seen that Spartina has colonised very unequally within the four sectors (fig. 5, tables 2 and 3). The upstream eastern shore contained $45-50 \%$ of the total area of Spartina in the estuary on the different survey dates; the downstream eastern shore contained 19-24\%; the upstream western shore contained $16-20 \%$, but the downstream western shore contained only $11-14 \%$. However, the areal distribution of sward and of clumps and shoots during the 20-year period changed in a similar way in the two upstream subdivisions, but in a different but internally similar way in the two downstream subdivisions (as described in more detail above).

\section{CROSS-PROFILE SURVEYS THROUGH SPARTINA MARSH}

The replicate cross-profile surveys reveal variations in ground surface height and width of the marsh within the intertidal zone. The site of the Rosevears profile (fig. 1) is an embayment on the upstream western Tamar shore, which contained an extensive Spartina sward in 1972, when it was first surveyed in conjunction with boring undertaken to investigate the depth of sediment trapped by the grass (Phillips 1975). A resurvey of this profile in 1977 , during the study of the tidal relationships of the marsh (Pringle 1982), revealed that no change had occurred since 1972 . However, changes have been apparent since 1977 (fig. 6). The Spartina sward extended $4 \mathrm{~m}$ landward into the fringe of native saltmarsh plants about HWM between 1977 and 1988. The lower channelward edge of the sward oscillated, showing a retreat of $9 \mathrm{~m}$ between 1977 and 1983, followed by an extension of $5 \mathrm{~m}$ by 1988 , but a small retreat of $1 \mathrm{~m}$ by 1991 . Spartina is an effective trapper of silt brought into the marsh in suspension on the flood tide. The rear and central parts of the marsh have shown slight variations in height, with a net rise of $0.1-0.2 \mathrm{~m}$ between 1977 and 1991. The lower part of the marsh, however, has risen steadily to about $0.4 \mathrm{~m}$ above its 1977 height. The well-defined continuous lower limit of the Spartina sward has been maintained despite the horizontal movements in its position, and it has shown little variation in height, only a slight overall lowering from $1.57 \mathrm{~m}$ Low Water Ordinary Spring Tide (LWOST) (Launceston - Batman Bridge) in 1972 to $1.49 \mathrm{~m}$ in 1991.

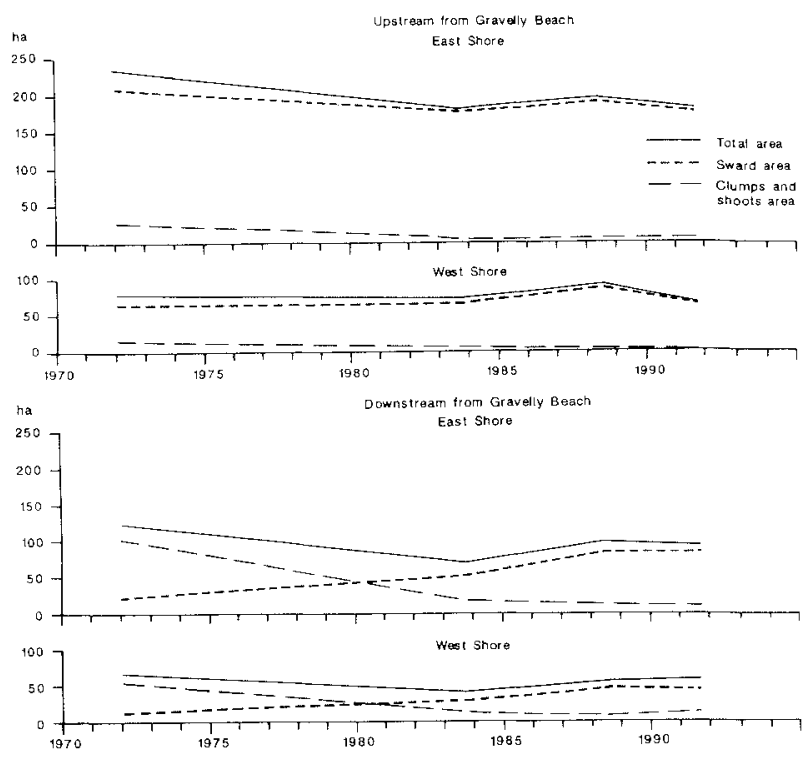

FIG. 5 - Area of Spartina anglica in four sectors of Tamar Estuary $1971 / 72$ to 1991.

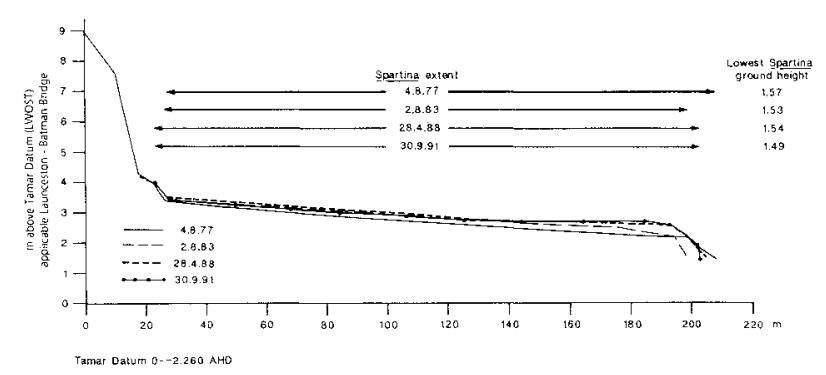

FIG. 6-Rosevears Spartina marsh cross-profiles 1977-91.

Lowest Spartina

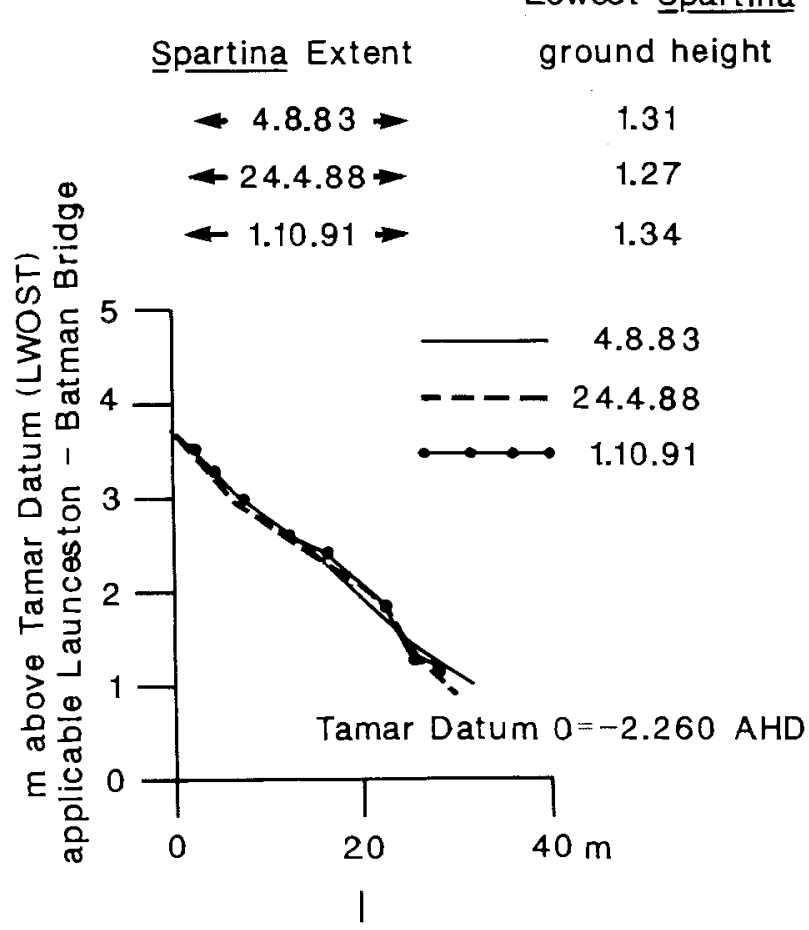

FIG. 7 - Windermere Spartina marsh cross-profiles $1983-$ 91. 


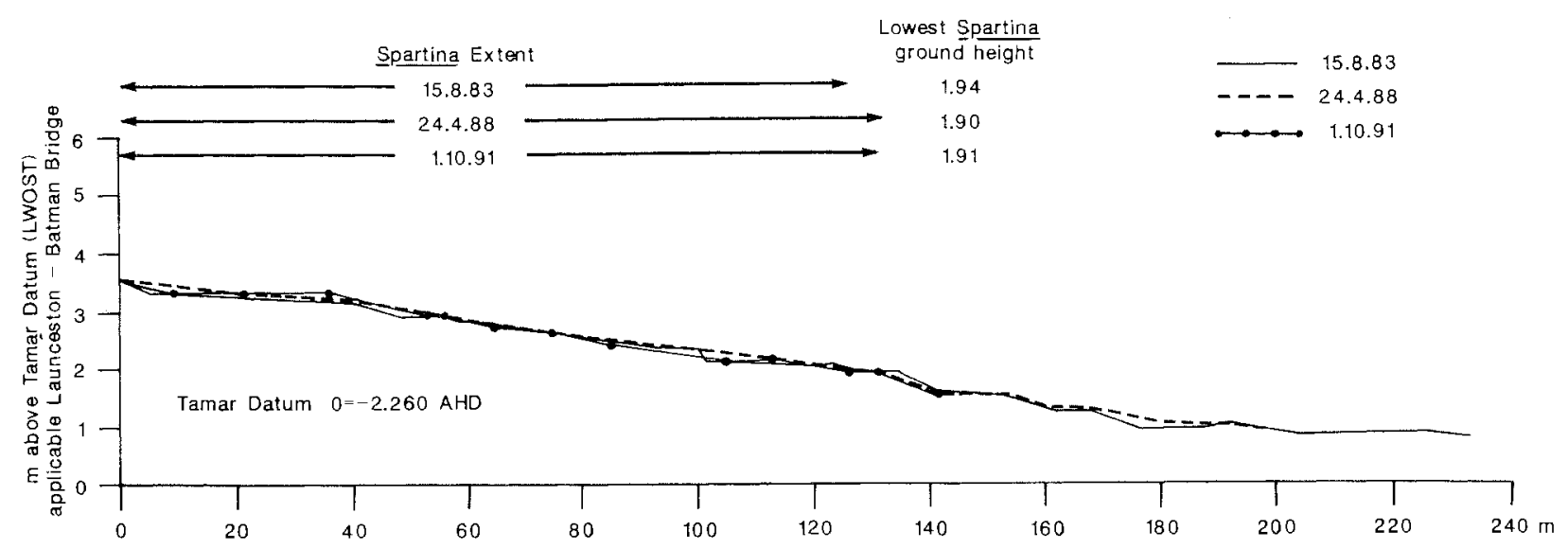

FIG. 8 - Swan Bay Spartina marsh cross-profiles 1983-91.

The Windermere profile (fig. 1), established in collaboration with the PLA in 1983, is sited on the same alignment as the Rosevears profile but on the opposite shore of the Tamar. The narrow Spartina sward, here growing in mud over basalt, extended $1 \mathrm{~m}$ landward between 1983 and 1988 (fig. 7), but otherwise has shown no change in extent up to 1991. Near the rear of the marsh, there have been slight variations in height but no net change between 1983 and 1991, whereas the lower, channelward part rose by $0.1 \mathrm{~m}$. The continuous lower limit showed only a slight variation in height, between $1.31 \mathrm{~m} \mathrm{LWOST}$ in 1983, 1.27 $\mathrm{m}$ in 1988 and $1.34 \mathrm{~m}$ in 1991.

Whereas the Rosevears and Windermere profiles are sited in the section of the Tamar upstream from Gravelly Beach, the third profile, established in collaboration with the PLA in 1983, is at Swan Bay, within the downstream section (fig. 1). At the time of the 1971/72 field survey, only clumps and shoots of Spartina were colonising this part of the eastern Tamar shore, where ferricrete outcrops extensively. However, by 1983 Spartina sward had developed, especially along the upper part of the profile. The upper limit lies at the foot of a concrete revetment, therefore it cannot extend in this direction (fig. 8). The lower edge of the marsh extended $6 \mathrm{~m}$ towards the distant channel between 1983 and 1988 but retreated $1 \mathrm{~m}$ by 1991. The lower part of the Spartina marsh showed slight variations in height between 1983 and 1991 but little net change. The upper part of the marsh, where Spartina sward has been longest established, increased in height by $0.1-0.2 \mathrm{~m}$. The discontinuous lower limit of the marsh, where Spartina shoots grow amongst ferricrete and oysters, with some mud present, has shown little height variation between $1.94 \mathrm{~m}$ LWOST in $1983,1.90 \mathrm{~m}$ in 1988 and $1.91 \mathrm{~m}$ in 1991.

The changes described above along the cross-profiles at Rosevears, Windermere and Swan Bay (figs 6, $7 \& 8$ ), have been supported also by the results of the annual surveys undertaken by the PLA between 1984 and 1989 (PLA records 1984-89).

\section{INTERRELATIONSHIPS WITHIN THE SPARTINA DISTRIBUTION PATTERN}

\section{Variations Relating to Geology/Substrate}

The overall distribution pattern appears to be strongly influenced by the geology/substrate. The fact that from 45 $50 \%$ of the total area of Spartina in the Tamar Estuary between 1971 and 1991 (table 3) has been in the eastern shore section, upstream from Gravelly Beach, can partly be explained by its long period of colonisation since its introduction at Windermere in 1947. However, it has also been influenced by the extensive intertidal mudflats present at Nelsons Shoal, since, as demonstrated earlier (Phillips 1975), although it is able to colonise any of the rock types and sediments along the shores of the central Tamar Estuary, Spartina shows a clear preference for the fine sediment of the intertidal mudflats. Within this upstream eastern section of the estuary, narrow, rocky intertidal zones are found only at Dilston, where dolerite outcrops, and at Windermere, where basalt outcrops downstream of the Spartina introduction site. At these points, only a narrow sward fringes the shore, and some of this has been removed by Windermere properry owners.

Despite the similar length of time in which Spartina has colonised the upstream western shore, only $16-20 \%$ of the total area in the estuary is found here. The reasons appear to be that

- the intertidal mudflats form only a narrow strip approximately parallel to the shore;

- there are no extensive shoals or major embayments; also - outcrops of basalt, between Loch Lea and Rosevears, and of dolerite, between Rosevears and Gravelly Beach, produce narrow, rocky shores, where only a narrow Spartina sward has been able to develop.

The rocky basalt shores with little fine sediment, e.g. near Lone Pine Point, continue to provide the least hospitable substrate for the grass (Phillips 1975), as shown by the presence of only coalescing clumps with patches of bare basalt outcrops and pebbles by 1991 .

Of the four sections discussed, the downstream eastern shore section contains the second largest area of Spartina, covering 19-24\% between 1971/72 and 1991. Swan Bay contains extensive intertidal mudflats, but in the smaller bays upstream of Egg Island Point and in Spring Bay and Ruffins Bay, they are less extensive. Ferricrete outcrops on 
some of the mudflats. In 1971/72, limited areas of sward had developed near the head of some of these bays, but Spartina was present mainly in the earlier colonising form of clumps and shoots. Subsequently, these have coalesced to produce an increasing area of sward. Except for these bays, there are long, rocky shores of dolerite between Swan Bay and Egg Island Point, and of basalt further downstream, colonised only intermittently by Spartina, which forms clumps and limited areas of sward, mainly in small bays.

The smallest area of Spartina, only 11-14\% in the period $1971 / 72$ to 1991 , is found in the section which lies downstream of Gravelly Beach on the western shore. It is mainly in the intertidal mudflats in the bay between Little Swan Point and Swan Point, in Supply Bay, Devils Elbow and Ruffins Bay. In 1971/72, there were only small areas of sward, and Spartina was mainly in separate clumps and shoots. However, the area of sward has steadily increased up to 1991 , as the clumps have coalesced. The rocky dolerite shore, between Supply Bay and the upstream end of Deviot, contains limited areas of clumps and swards, mainly in small bays, but the basalt shore at Deviot was still almost completely clear of the grass in 1991, again indicating the inhospitable nature of this rock for Spartina colonisation.

\section{Variations in Area of Sward, Clumps and Shoots, $1971 / 72$ to 1991}

The slow initial colonisation of Spartina in the Tamar Estuary in the late 1940 s and 1950 s, followed by its more rapid expansion, especially in the late 1960s to early 1970s, has been considered earlier (Phillips 1975) and reviewed above. The later fluctuations in total Spartina area (fig. 2) will now be considered in relation to changes in area of sward and of clumps and shoots in the four sections designated (table 2, figs 3, 4 \& 5).

The reduction in total area, from 512 ha in 1971/72 to 367 ha in 1983, resulted from a marked fall in area of clumps and shoots on both eastern and western shores downstream from Gravelly Beach, and a slight fall in their area on both shores upstream. At the same time, the area of sward was clearly increasing on both downstream shores and slightly increasing on the upstream western shore. Only on the upstream eastern shore was there a slight fall in sward area. The overall reduction in area of clumps and shoots suggests that, after the very rapid expansion in area up to about 1971/72, some ecological change or genetic change in the Spartina affected mainly the least well-established plants (growing in clumps and as shoots) but had little effect on the swards.

The renewed increase in total area, from 367 ha in 1983 to 447 ha in 1988, resulted from an increase in sward area, although the area of clumps and shoots continued to fall slowly in all the four sections of the Tamar Estuary. The sward area increased partly because clumps and shoots coalesced into this more mature form of marsh, but the sward also spread beyond its earlier limits.

The smaller fall in total area, from 447 ha in 1988 to 412 ha in 1991, occurred mainly on the upstream eastern and western shores and slightly on the downstream eastern shore, However, the total area increased slightly on the downstream western shore. On both upstream shores, the fall was caused mainly by a reduction in sward area, combined with a small decrease in area of clumps and shoots. On the downstream eastern shore, there was a small reduction in area both of sward and of clumps and shoots. The downstream western shore also showed a slight reduction in sward area, but an increase in area of clumps and shoots, which explains the overall rise in Spartina area here.

This second period of overall reduction in Spartina area may have had a different cause from the earlier one, between 1971/72 and 1983, because the fall affected mainly Spartina sward, especially along both upstream shores. This will be considered further below, in relation to Spartina marsh maturity.

\section{Links between Area and Cross-profile Changes $1971 / 72$ to 1991}

Although the three cross-profiles have been surveyed regularly only since 1983 , it is possible to demonstrate a tentative link between the area changes discussed above and the profile changes. Only the Rosevears profile was surveyed in $1971 / 72$ and 1977 and showed no change in length. However, by 1983 , during the period of overall reduction in area, the lower edge of the Rosevears Spartina sward had retreated by $9 \mathrm{~m}$ (despite a slight increase in total sward area on the upstream western shore including Rosevears).

During the following period of increase in total Spartina area, between 1983 and 1988, the lower edge of the Rosevears sward advanced $5 \mathrm{~m}$ channelward, whilst the upper edge advanced $3 \mathrm{~m}$ landward. Also, the clumps and shoots of the lower part of the Swan Bay profile advanced $6 \mathrm{~m}$ channelward. Only the Windermere profile showed no change to its lower edge position, but its upper sward edge advanced $1 \mathrm{~m}$ landward. In addition to these profile length changes, the heights of the lower marsh edge lowered from $1.94 \mathrm{~m}$ to $1.90 \mathrm{~m} \mathrm{LWOST}$ at Swan Bay and from $1.31 \mathrm{~m}$ to $1.27 \mathrm{~m}$ at Windermere.

During the second lesser period of reduction in total area, between 1988 and 1991, the lower edge of the Rosevears and Swan Bay profiles retreated landward by $1 \mathrm{~m}$ each, whilst the Windermere profile showed no change. At the same time, the height of the lower marsh edge rose slightly from $1.90 \mathrm{~m}$ to $1.91 \mathrm{~m} \mathrm{LWOST}$ at Swan Bay and from $1.27 \mathrm{~m}$ to $1.34 \mathrm{~m}$ at Windermere. (Only the Rosevears profile has shown a general trend of lowering of the lower marsh edge between 1977 and 1991, from $1.57 \mathrm{~m}$ to $1.49 \mathrm{~m}$.

\section{MATURING OF THE SPARTINA MARSH}

Many of the changes already examined reflect the maturing of the Spartina marsh. After its rapid colonisation of the central Tamar mudflats during the 1960s, in the form of shoots which expanded into clumps, some had coalesced into the mature form of sward by the summer of 1971/72. These sward areas were found mainly upstream of Gravelly Beach, including an extensive area on Nelsons Shoal (table 2 , figs $4 \& 5$ ). The sward developed first near HWM and subsequently extended into the central and lower parts of the intertidal mudflats. In 1971/72, most of these upstream sward areas were fringed with clumps and shoots along their lower edge, but in a few places the sward formed a continuous lower edge near LWM (e.g. near Rostella and around Native Point on the eastern shore; along parts of the Legana shore and at Rosevears downstream of Cimitiere Point on the western shore). Downstream of Gravelly Beach Spartina 
was mainly growing as shoots and clumps, with only small areas of mature sward mainly in embayments.

By 1983, the Spartina marsh had matured considerably, as discussed in detail in a report to the PLA (Pringle 1983). It had extended about $3 \mathrm{~km}$ upstream from Dilston and Dog Point, as a sward fringing the lower edge of the native marsh. In the main areas of colonisation in 1971/72, upstream of Gravelly Beach, Spartina formed a sward with a continuous lower limit at about high low water mark (HLWM) by 1983. This appeared to represent the maximum possible extent of the marsh towards the channel, under ecological conditions prevailing at that time. In places (e.g. near the Rosevears cross-profile line, fig. 6), a small erosional cliff had formed since 1971/72 along the lower marsh edge, and this had reduced the total area of sward. In a few areas (e.g. around Nelsons Shoal, in Muddy Creek and along the basalt shores at Windermere and near Lone Pine Point), the Spartina sward was still fringed with clumps and shoots, indicating that it had not yet reached its fully mature extent.

Dowstream of Gravelly Beach, by 1983, the maturing of the marsh was indicated by the increase in sward area (figs 4 $\& 5$ ), as clumps and shoots coalesced. Occurring mainly in the bays, this produced larger areas of sward than in 1971/72, although these continued to have a fringe of clumps and shoots along their lower edge, indicating that full maturity had not yet been reached. However, some of the earlier areas of clumps and shoots had been lost, giving the overall reduction in Spartina area between 1971/72 and 1983.

Since 1983, the trend towards a mature Spartina sward has continued steadily throughout most of the central Tamar estuary. Upstream of Gravelly Beach, the area of sward expanded channelward in many places up to 1988 but continued to show a well-defined continuous lower limit. Since 1988 , it has suffered a little erosion and retreat. A fringe of clumps and shoots is still present along the same sections of marsh as in 1983 , most notably on the downstream side of Nelsons Shoal. The younger marsh, downstream of Gravelly Beach, showed mainly an expansion of sward, as clumps and shoots coalesced, but on the western shore, since 1988, the sward area has been reduced slightly, whilst the area of clumps and shoots has expanded. Even the most extensive areas of sward still had a fringe of clumps and shoots in 1991, indicating that they were not fully mature.

Periods of overall expansion of Spartina marsh have been achieved primarily by the extension of sward channelward, and also laterally where space permitted. Reductions in overall area have been achieved in different ways, depending on the state of maturity of the marsh. At the earlier stage, between $1971 / 72$ and 1983, the reduction resulted from the loss of clumps and shoots primarily, whilst during the later stage, between 1988 and 1991, it resulted mainly from erosion along the lower edge of the sward. In both cases, the lower edge of the Spartina marsh retreated shorewards. There may be a number of reasons for the varying position of the lower edge through time.

\section{Tidal Influences on the Lower Marsh Edge}

The tidal regime of the Tamar Estuary is transitional between semi-diurnal and diurnal (Pringle 1982), with a characteristic tidal sequence of low low, low high, high low, high high. Successive high tides have only about half the height difference experienced by successive low tides.
The tidal immersion of the marsh was examined for 1977, with particular reference to the mature Rosevears marsh, where the maximum spring tide range was $3.9 \mathrm{~m}$ and the minimum neap range was $2.1 \mathrm{~m}$. The marsh crossprofile was related to recorded and predicted tidal curves, in order to investigate variations in depth and period of immersion in different parts of the marsh. This revealed that, whilst the whole marsh was immersed on all high tides to a depth of between $0.2 \mathrm{~m}$ and $1.0 \mathrm{~m}$ above ground level near its upper limit, the lower limit lay at the height of the highest high low tides but fully emerged on all low low tides.

As Hubbard (1969) indicated, the tidal immersion of a marsh may alter many environmental conditions within the habitat, including moisture content, salinity, aeration, light intensity and duration, and temperature, in addition to physical changes produced by intermittently present wave and current action. Ranwell et al. (1964) indicated that the tidal immersion limit for Spartina in Poole Harbour, Dorset, UK was $5800 \mathrm{hy}^{-1}$, whereas the tidal immersion time for the Rosevears Spartina marsh was 6650 h for 1977 (Pringle 1982). Hubbard (1969) observed that the maximum continuous immersion of the lowest level of the Poole Harbour marsh was 23.5 h per day during a neap winter tide; this was similar to conditions on the Rosevears marsh on the highest HLWs between May and July in 1977.

As the cross-profiles have shown, the height of the lowest Spartina growth has varied only slightly at each locality: at Rosevears 1.49-1.57 m LWOST (Launceston - Batman Bridge), at Windermere $1.27-1.34 \mathrm{~m}$, and at Swan Bay $1.90-1.94 \mathrm{~m}$. This does suggest there is a limiting control operating. It was demonstrated earlier (Pringle 1982) that the lowest Spartina level at Rosevears in 1977 (1.57 m) was at the height of the highest HLW level for that year, and small variations may result from changing tidal conditions from year to year. The reason for the difference between Rosevears and Windermere heights of about $0.2 \mathrm{~m}$ is more difficult to explain, as the two sites are opposite each other on western and eastern Tamar shores respectively. Strong tidal currents occur in this relatively narrow constricted section of the estuary, and general observations indicate that, on the flood tide, higher velocities occur near the Rosevears shore than along the Windermere shore; this pattern may be reversed on the ebb tide. This could produce a lateral surface water gradient downwards towards the area of fastest ebb flow and, if so, might depress the LW level at Windermere slightly. In addition, the rocky basalt substrate at Windermere provides a firmer anchor for the plants than the finer sediment substrate at Rosevears; this may enable them to grow to a slightly lower level.

An increase in tidal range occurs from the mouth of the Tamar Estuary towards its head at Launceston. Foster et al. (1986), in a series of tidal measurements in March-April 1985, demonstrated a variarion between MHW and MLW of $2.34 \mathrm{~m}$ at Georgetown and $3.25 \mathrm{~m}$ at Launceston. The variation between $2.54 \mathrm{~m}$ at Deviot and $2.81 \mathrm{~m}$ at Rosevears helps to explain the difference in the height of the lower edge of the Spartina marsh at Swan Bay as compared with that at Rosevears. In addition, the Swan Bay site lies in a broader section of the estuary, well away from the strong tidal currents of the channel. 


\section{Meteorologically Controlled Influences on the Lower Marsh Edge}

As well as the tidal control on the position and height of the lower limit of the Spartina marsh, this edge will also be influenced by variations in river discharge into the estuary. The main catchments are those of the North Esk River $\left(1067 \mathrm{~km}^{2}\right)$ and South Esk River $\left(8609 \mathrm{~km}^{2}\right)$ (fig. 1). Foster et al. (1986) demonstrated seasonal variations in flow, with highest flows in winter and spring and lowest flows in summer and autumn reflecting the rainfall pattern. The Trevallyn/Poatina Hydro-Electric Power Scheme, which came into operation in two stages, in 1955 and 1965, with a subsequent addition in 1977 , has involved the diversion of water into the South Esk from the Great Lake under low flow conditions. This has reduced the incidence of low river flow into the Tamar. However, because the Trevallyn reservoir is small, it has little effect on flood flows into the estuary, and it is the frequency and height of flood events which may influence the lower limit of the Spartina marsh.

In addition to influencing river discharge, meteorological conditions may affect tide height and tidal current velocities, through strong winds and atmospheric pressure variations. Foster et al. (1986) suggested that resulting storm surges develop in Bass Strait and may result in variations in tide levels in the Tamar Estuary of $0.5-1 \mathrm{~m}$. Strong winds, which they found were mainly from between WNW and NNW and were associated with high pressure, distort the shape of the tidal curve in the estuary, and this effect becomes more marked with distance up the estuary. The duration of the flood tide is increased, whilst the ebb is decreased. Therefore, flood tide velocities are decreased whilst ebb velocities are increased.

\section{Human Influences on the Lower Marsh Edge}

As well as being influenced by normal astronomical tide conditions, the lower edge of the Spartina marsh may also be affected, therefore, by such meteorologically controlled events as river floods and abnormal tidal variations. There may be a human influence as well. Launceston was the main port on the Tamar Estuary between about 1800 and the mid-1960s; after 1890, dredging was needed to enable increasingly large ships to pass along the estuary. After the mid-1960s, port facilities were moved downriver to Bell Bay to cater for larger container ships and, therefore, dredging was reduced. This has affected not only the main channel, and tidal velocities within it, but also sedimentary conditions on the adjacent mudflats. Although commercial shipping has been reduced in the Tamar in recent decades, recreational pleasure boat activities have increased and, as Foster et al. (1986) noted, this may lead to a pronounced increase in mudbank erosion and release of suspended sediment.

\section{Influences on the Upper Marsh Edge}

In describing the maturing of the Spartina marsh, it was noted that the upper edge had extended slightly shoreward in some places into the narrow zone of native Tasmanian saltmarsh vegetation about HWM. The marsh first reaches the mature sward stage near its upper limit and further changes have been observed here in certain localities since 1983. During the winter, when most of the plant above the ground surface dies back, some is broken off by wave and tidal action. It floats in the tidal currents before being deposited in some relatively sheltered bays, or near HWM along shores with a particularly long fetch. This can form such a thick thatch that the plants buried beneath it are unable to sprout and grow through it during the following spring and summer. As a result, by 1991 a strip of earlier sward up to about $25 \mathrm{~m}$ wide near HWM had been destroyed, especially in embayments in the more mature marsh upstream of Gravelly Beach, and also in Swan Bay and near Swan Point downstream.

This trend may be expected to continue and even escalate because, as the sward area increases with the whole Tamar Spartina marsh maturing further, the quantity of dead plant remains will increase each winter. Slightly offsetting this is the human effect produced by removal of dead thatch from more accessible shores for use as a garden mulch.

\section{CONCLUSIONS}

\section{Physical Effects of Spartina Colonisation on the Tamar Estuary}

The colonisation of large areas of the Tamar Estuary intertidal mudflats by Spartina, since its introduction from England via South Australia in 1947, has had considerable physical effects (in addition to the biological changes which are outside the scope of this paper). After rapid expansion to cover over 500 ha in the $1971 / 72$ summer, it was reduced but has shown fluctuations in total area up to 1991, when it covered 412 ha. It has at least partially fulfilled the aims of the introduction, to stabilise and raise the mudflats and to constrain channel movements.

Borings through the mature Rosevears and Windermere marshes in 1972 revealed Spartina root remains in fine sediment to maximum depths of $2.29 \mathrm{~m}$ and $2.35 \mathrm{~m}$ respectively (Phillips 1975). Foster et al. (1986) compared three cross-sections of Nelsons Shoal surveyed in 1986 with a survey of the whole shoal by Clerke in 1889, and deduced that it has acted as a substantial sediment sink, especially in the now Spartina-covered areas where about $1 \mathrm{~m}$ of siltation has occurred. They estimated that Spartina was colonising about $5.3 \mathrm{~km}^{2}$ of Nelsons Shoal in 1986 and that the total quantiry of sediment trapped in this area during the 97 years was between 5 and 10 million $\mathrm{m}^{3}$ or 50000 to $100000 \mathrm{~m}^{3} \mathrm{y}^{-1}$. The replicate cross-profile surveys discussed in this paper have revealed maximum rises of $0.4 \mathrm{~m}$ along the lower part of the Rosevears profile 1977-91; $0.1 \mathrm{~m}$ along the lower part of the Windermere profile 1983-91; and $0.1-0.2 \mathrm{~m}$ along the upper part of the Swan Bay profile 1983-91.

As the mature Spartina sward, which was well-developed above Gravelly Beach by 1983 , extends down to about HLWM, the main channel is constrained within narrower limits than before the grass was introduced. However, in the narrow sections of the estuary especially, waves and tidal currents are able to erode the lower marsh edge at times.

Whilst these effects of stabilising the mudflats by trapping silt and constraining the main channel may be regarded as beneficial, Spartina colonisation is seen as detrimental in some other ways. Through its vigorous growth, it has engulfed many small jetties and invaded sand beaches from the mudflats to reduce the recreational facilities and attractions of the Tamar shores. 


\section{Spartina Control}

After the explosive spread of Spartina in the late 1960s to early 1970 s, its colonisation of the mudflats has been largely uncontrollable. Herbicides proved to be ineffective, mainly because of the tidal regime in which every HW immerses the whole marsh at least near ground level. In addition, there have been concerns about unwanted side effects, which were felt especially during a period of commercial oyster cultivation in the estuary.

Regular physical removal by digging out was practised by the PLA, during the 1980s, at a number of recreationally important sites, and by other bodies. This proved successful but was labour intensive. Individual property owners have employed similar methods, together with burning the grass along their shore; others mow it to reduce it to a short turf, which allows easy access to small jetties. On a larger scale, cattle and sheep are grazed on the Spartina marsh where the substrate is relatively firm, e.g. in Spring Bay and Redwood Bay. It provides valuable fodder, especially towards the end of summer when the pastures are drying; the cattle reduce the Spartina height to about $80 \mathrm{~mm}$, while the sheep reduce it to about $20 \mathrm{~mm}$. Whilst all these methods have been reasonably successful, they are controlling only a very small proportion of the total Spartina area in the Tamar Estuary.

\section{The Future for Spartina in the Tamar Estuary}

The colonisation and effects of Spartina have been examined mainly for the period 1971-91. Whilst most of the Spartina marshes reached the mature sward stage in the estuary upstream of Gravelly Beach, there were still, in 1991, some areas of bare mudflats above the general lower limit of HLWM, the most extensive of which lies along the downstream side of Nelsons Shoal. The sward can be expected to extend into these. The fluctuations observed along the mature lower marsh edge are likely to continue, primarily as a result of variations in tidal conditions and river discharge. The death of a belt of sward near HWM, as dead winter thatch stifles subsequent growth, is likely to become more extensive along the shore, as long as summer growth rates in the marsh generally are maintained. Mature marsh levels are expected to rise as the grass continues to trap sediment brought onto the marsh in suspension on the flood tide.

Downstream of Gravelly Beach, the less mature Spartina marsh is expected to continue its development towards maturity, firstly in the embayments with mudflats. Some extension of the marsh along the rocky shores may occur slowly to produce a narrow fringe of sward. The death of a belt of sward near HWM, already occurring especially in Swan Bay and near Swan Point, is likely to extend further at the rear of expanding areas of mature sward. When sward has extended to HLWM it may be expected to show similar fluctuations in position to those already seen upstream of Gravelly Beach, and the mature marshes will rise as they trap sediment.

All these projected changes are likely to take place in the estuary between about Tamar Island upstream and East Arm downstream. As there has been no significant extension upstream since 1983, nor downstream since 1972, it seems unlikely that this will occur naturally in the near future.

\section{ACKNOWLEDGEMENTS}

I should like to thank all those in Tasmania who have helped with this long-term project: Prof. J.L. Davies (now in Sydney), who first introduced me to the problem of Spartina in the Tamar Estuary; the Geography Department of the University of Tasmania, which kindly provided me with Study Leave facilities; the Port of Launceston Authority, which has helped in many practical ways with the freld surveys; and $\mathrm{Mr}$ and Mrs H.K. Joyce and $\mathrm{Mr}$ and Mrs W.H. Merry for their kind hospitality and support during fieldwork. Also I am grateful to my husband, George, for his field assistance and general encouragement with the project; to Miss Claire Jarvis and Mr Matthew Ball for drawing the maps and diagrams, and to Mrs Marlene McNaught for typing the manuscript of this paper in the Geography Department at Lancaster University.

\section{REFERENCES}

Boston, K.G., 1981: The introduction of Spartina townsendii (S.L.) to Australia. Occ. Pap. 6, Melbourne Stare Coll.: 57 pp.

Foster, D.N., NitTIM, R. \& WALKER, J., 1986: Tamar River siltation study. Tech. Rep. Water Res, Lab. 85/07, Univ. NSW: 143 pp.

Gray, A.J., Benham, P.E.M. \& Raybould, A.F., 1990: Spartina anglica - the evolutionary and ecological background. In Gray, A.J. \& Benham, P.E.M. (Eds): SPARTINA ANGLICA - A RESEARCH REVIEW. ITE Res. Publ. 2. NERC, HMSO, London: 5-10.

HUBbard, J.C.E., 1969: Light in relation to tidal immersion, the growth of Spartina townsendii (SL). J. Ecol. 57: 795-804.

MARKS, T.C. \& Mutins, P.H., 1990: The seed biology of Spartina anglica. In Gray, A.J. \& Benham, P.E.M. (Eds): SPARTINA ANGLICA - A RESEARCH REVIEW. ITE Res, Publ 2. NERC, HMSO, London: 20-25.

Martin, G.J., 1971: Background information on the rice grass areas in Tasmania, 5 November, in litt. (unpublished).

PHILLIPS, A.W., 1975: The establishment of Spartina in the Tamar Estuary, Tasmania. Pap. Proc. R. Soc. Tasm. 109: 65-75.

PrIngLE, A.W., 1982: Tidal immersion of the Tamar Estuary Spartina marsh, Tasmania, Australia. Pap. Proc. R. Soc. Tasm. 116: 143-152.

Pringle, A.W., 1983: A report for the Port of Launceston Authority, Tasmania, on the Tamar Estuary Spartina (rice grass) marshes 1983. Dep. Geography, Lancaster Univ.: 25 pp.

Prungle, A.W., 1988: Condition and distribution of Spartina (rice grass) in selected estuaries and inlets along the Bass Strait coast, Tasmania. Rep. for Tasm. Dep. Lands, Parks and Wildlife: $15 \mathrm{pp}$.

RaNwELL, D.S., 1967: World resources of Spartina townsendii (sensu lato) and economic use of Spartina marshland. J. Appl. Ecol. 4: 239-256.

Ranwell, D.S., Bird, E.C.F., Hubbard, J.C.E. \& Stebbings, R.E., 1964: Spantina saltmarshes in southern England. V. Tidal submergence and chlorinity in Poole Harbour. J. Ecol. 52: 627-641.

Sмrrt, J.S., 1982: The Spartina communities of the Cromarty Firth. Trans. Bot. Soc. Edin. 44: 27-30.

Tном, B.G. \& Roy, P.S., 1985: Relative sea levels and coastal sedimentation in South East Australia in the Holocene. J. Sedim. Petrol. 55(2): 257-264.

Whiteside, M.R., 1987: Spartina colonization. In Robinson, N.A. \& Pringle, A.W.: Morecambe Bay - an assessment of present ecological knowledge. Morecambe Bay Study Group in conjunction with Centre for North West Regional Studies, Lancaster University: 118-129. 